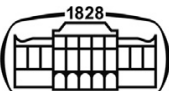

AKADÉMIAI KIADÓ

UNIVERSITY of DEBRECEN

\section{International Review of Applied Sciences and Engineering}

13 (2022) 1, 70-79

DOI:

10.1556/1848.2021.00309

(c) 2021 The Author(s)

\section{REVIEW PAPER}

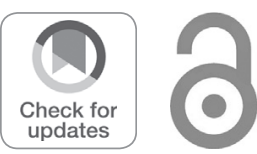

\title{
Effect of nano silica on the properties of concrete and mortar - A state of art
}

\author{
Pandiaraj Karthigai Priya* ${ }^{*}$ and Sankararajan Vanitha
}

Department of Civil Engineering, Kalasalingam Academy of Research and Education, Krishnankoil, 626126, Tamilnadu, India

Received: May 3, 2021 • Accepted: June 21, 2021

Published online: September 1, 2021

\begin{abstract}
Construction industry is one of the biggest sectors globally and a wide variety of materials are used to carry out various works. Particularly, cement is a material that is used in the construction of various structures and it is also the major source of emission of $\mathrm{CO}_{2}$ gas into the atmosphere which results in global warming. Many researchers have identified various replacement materials for cement as a partial substitution and carried out experiments successfully. Nano silica is widely utilized as a partial replacement for cement and a lot of research is carried out. This paper reviews the past studies in which nano silica is utilized in various building materials such as cement mortars, normal concrete and special concretes. The fresh concrete properties, strength and durability of the material are the parameters reviewed and it is apparent that by incorporating nano silica in cement it absorbs more water, which makes the mix less workable and it imparts additional strength to the concrete and also provides better durability when compared with the control specimen. Hence it has been revealed that nano silica will be a good replacement for cement as it is pozzolanic in nature and also possessing good microstructure.
\end{abstract}

\section{KEYWORDS}

nano silica, cement, concrete, strength, durability

\section{INTRODUCTION}

Urbanization and industrialization pose a major threat to the environment hence instigating pollution to the environment and its surroundings. Carbon dioxide $\left(\mathrm{CO}_{2}\right)$ is emitted from cement production process and it alone accounts for $5-8 \%$ of the total $\mathrm{CO}_{2}$ emitted globally thus resulting in global warming [42]. A lot of materials have been identified and replaced for cement in order to diminish the effect of $\mathrm{CO}_{2}$ emission from the cement manufacturing process. Silica fume is one among them most widely used as a replacement for cement and a lot of research is carried out with the utilization of silica fume especially in nano form and validated [46].

Silica fume is produced from several methods and one common method of silica fume production is through the reduction process of quartz to silicon at $2000{ }^{\circ} \mathrm{C}$ in which silicon dioxide vapor is produced which is then oxidized and condensed at low temperature to obtain silica fume [43]. Silica fume rice husk, a solid waste and a by-product from rice cultivation, poses major problems to the environment if not managed properly. The amorphous silica is produced from rice husk after it has been subjected to various high pressures and temperatures as it has a high organic content that needs to be removed [1]. Silica fume is obtained after the rice husk is subjected to chemical treatment and further burning it. Silica fume can also be produced by various other processes such as sol gel process, pyrogenic process, reduction process of quartz while manufacturing silicon and ferrosilicon and acid leaching procedure. For this purpose, acids like Hydrochloric acid, Sulphuric acid, Oxalic acid, Citric acids are generally used to obtain silica fume. Also, the silica fume finds its common application in construction materials $[2,4]$. In the recent past, the utilization of nano materials in construction has played a significant role in various applications. 
Especially, nano silica finds its application widely in concrete due to high specific surface area, which also improves the strength and durability of the concrete [44]. Apart from nano silica, many other materials, for instance, nano $\mathrm{TiO}_{2}$, nano $\mathrm{Fe}_{2} \mathrm{O}_{3}$, nano $\mathrm{Al}_{2} \mathrm{O}_{3}$, etc. are used as construction materials [45].

This paper reviews the characteristics and properties of nano silica when replaced for cement in various concretes and its suitability for replacing it as construction material. The performance of different concretes in terms of strength and durability is studied when silica fume is replaced in it for cement. This paper gives an idea about the proportion of nano silica and silica fume that can be utilized in different concretes so that it improves the mechanical and durability properties of the material in which it is being utilized.

\section{REVIEW FROM PAST RESEARCH}

\subsection{Characteristics of nano silica from past research}

The silica fume is generally called as nano silica when the particle size is between 1 and $700 \mathrm{~nm}$ and having high specific surface area. The chemical composition of nano silica is studied using X Ray Fluorescence Spectroscopy and it is found that a large amount of $\mathrm{SiO}_{2}$ is present in silica fume, and other elements such as $\mathrm{Al}, \mathrm{Fe}, \mathrm{Mg}, \mathrm{Na}$ and $\mathrm{K}$ are found in trace amounts. So, it can be said that nano silica acts as a good pozzolanic material as it is having high silica content [44]. The size of the particle was found by Scanning Electron Microscopy (SEM) and it showed that the particle size of silica fume ranges from 2 to $720 \mathrm{~nm}$. The size of the nano silica will vary based on the production process adopted for manufacturing of silica fume [3]. The average particle size is $40 \mathrm{~nm}$ of the nano silica utilized in this study [8]. It also acts as a better pore filler in concrete as the size of the element is much smaller thus it will have high specific surface area [44].

The relative density and the bulk density of the nano silica was found to be around 1.2 and $1,200 \mathrm{~kg} \mathrm{~m}^{-3}$ respectively. The specific surface area of the nano silica is $250 \mathrm{~m}^{2} \mathrm{~g}^{-1}$ and the $\mathrm{pH}$ value is 6.8 . The specific gravity of the nano silica is nearly 2.33 and it is found lesser then the specific gravity of cement [26].

\subsection{Nano silica as replacement material}

Table 1 shows partial replacement of nano silica with construction materials and the corresponding effect in terms of strength and durability.

\subsection{Mechanical properties of concrete with nano silica}

2.3.1. Cement mortar. The compressive strength of the mortar manufactured by replacing cement with nano silica was found higher when compared with conventional mortar when nano silica replacement was at $12 \%$ [8]. As mentioned by Luciano Senff et al., it is evident that the requirement of water decreases in cement mortar when replaced with $2.5 \%$ of NS [10]. With nano silica replaced at 3\% for cement in concrete mortar the compressive strength was found to be higher when compared with the control specimen [11]. This may be due to the pozzolanic reaction of the nano silica, which is found effective and it fills the pores thus enhancing the strength of the mortar. In a study carried out by Sattawat Haruehansapong et al., nano silica of various sizes of $12 \mathrm{~nm}$, $20 \mathrm{~nm}, 40 \mathrm{~nm}$ is replaced for cement in cement mortar. The increase in replacement of NS improved the strength, however, at $9 \%$ replacement the mortar possessed high mechanical strength and the size of the nano silica did not have any effect on the mortar [31]. The mechanical strength of the mortar increases with increase in nano silica replaced for cement [5]. The compressive strength of cement mortar manufactured with nano silica carried out by different researchers is compared and is presented in Fig. 1.

2.3.2. Recycled concrete. Recycled concrete was manufactured and replaced with nano silica for cement and it is tested at various elevated temperatures and it is found that the compressive strength has a tendency to decrease with increase in percentage replacement of nano silica content and the compressive strength also decreases with increasing elevated temperature. The vapor pressure occurs due to the evaporation of the adsorbed and capillary water when the temperature is between 25 and $200{ }^{\circ} \mathrm{C}$ and thereby it tends to reduce the strength of the concrete [12]. The compressive strength decrease is due to the vapor pressure that affects the internal microstructure of the concrete. Musab Alhawat et al., found that nano silica with $1.5 \%$ replacement for cement boosted the bond strength and corrosion resistance of the concrete in recycled aggregate concrete [26].

2.3.3. Geopolymer concrete. Partha Sarathi Deb et al. found that geopolymer concrete replaced with nano silica at $2 \%$ increased the compressive strength when compared with the control one. Beyond $2 \%$ of addition, the NS gets unreacted in the matrix, which considerably reduces the strength of the concrete [17]. D. Adak et al. stated in their study that the nano silica addition of $6 \%$ for cement in geopolymer mortar showed improvement in the mechanical properties of the plain cement mortar [28]. Currently nano silica is used in geopolymer concrete also. The combined effect of $1 \%$ SF with $2 \%$ NS possessed good mechanical properties in geopolymer concrete [14]. The combined effect of utilizing nano silica and silica fume each at $1.5 \%$ improved the microstructure of geopolymer concrete and it also possessed good compressive strength [15]. This could be due to the high rate of alkali activation reaction that takes place in geopolymer concrete $[14,15,17,28]$. Figure 2 shows the comparative chart of compressive strength of geopolymer concrete in which nano silica is incorporated at various percentages by various researchers.

2.3.4. High-performance concrete. When $2 \%$ NS is added to cement in high-performance self-compacting concrete, the performance of the concrete in terms of strength and 
Table 1. Nano silica replacement and its effects in various construction materials

\begin{tabular}{|c|c|c|c|c|}
\hline Ref. & Replacement material & $\%$ Replacement & $\begin{array}{l}\text { Material in which } \\
\text { replacement done }\end{array}$ & Tests done \\
\hline [5] & $\begin{array}{l}\text { Nano } \mathrm{Fe}_{2} \mathrm{O}_{3} \\
\text { Nano } \mathrm{SiO}_{2}\end{array}$ & $\begin{array}{c}\text { Nano silica }(\mathrm{NS})-2,3 \\
5,10 \% \text { for cement }\end{array}$ & Cement mortar & $\begin{array}{l}\text { Compressive strength, } \\
\text { flexural strength }\end{array}$ \\
\hline [6] & Colloidal silica (CS) & CS $-1 \& 5 \%$ for cement & Cement mortar & $\begin{array}{c}\text { Differential Scanning } \\
\text { Calorimetry (DSC) tests } \\
\text { @ 35-550 deg cel, } \\
\text { Fourier Transform } \\
\text { Infrared Spectroscopy } \\
\text { (FTIR) }\end{array}$ \\
\hline [7] & $\begin{array}{l}\text { Nano silica, incinerated } \\
\text { sewage sludge ash } \\
\text { (ISSA) }\end{array}$ & $\begin{array}{c}\text { NS }-1,2 \% \\
@ 1,10,75 \mu \mathrm{m} \text { for } \\
\text { cement } \\
\text { ISSA }-20 \% \text { for cement }\end{array}$ & Cement mortar & $\begin{array}{l}\text { Compressive strength, } \\
\text { Scanning Electron } \\
\text { Microscopy (SEM), X- } \\
\text { Ray Diffraction (XRD), } \\
\text { Mercury Intrusion } \\
\text { Porosimetry (MIP) }\end{array}$ \\
\hline [8] & $\begin{array}{c}\text { Nano } \mathrm{SiO}_{2} \text { and silica } \\
\text { fume }\end{array}$ & $\begin{array}{l}\text { SF }-5,10,15 \% \text { for } \\
\text { cement } \\
\text { NS - } 3,6,10,12 \%\end{array}$ & Cement mortar & $\begin{array}{c}\text { Compressive strength, } \\
\text { SEM, XRD }\end{array}$ \\
\hline
\end{tabular}

[9] $\quad \mathrm{Nano} \mathrm{SiO}_{2}$

@ $0,0.5,1,2,5 \%$ for $\quad$ Cement mortar cement

[10] Nano silica

[11] Nano silica

$@ 1,2,3,5 \%$ for cement

Cement mortar

[12] Nano silica \& basalt fiber

\author{
NS - 0, 3, 6\% for \\ cement \\ Basalt fiber - 1, 2, 3\% by \\ weight of cement
}

[13] Colloidal nano silica

@ $0.75,1.5,3 \%$ for cement

NS $-2 \%$

Steel fiber $-0.5,1,1.5 \%$

Geopolymer concrete

[15] NS \& silica fume (SF)
Compressive strength, flexural strength, SEM, XRD

Concrete (GPC)
Geopolymer concrete (GPC)
Compressive strength, flexural strength, SEM

Viscosity, flow table, apparent density, XRD$$
\text { XRD }
$$

Recycled concrete
Compressive strength, tensile strength, SEM, XRD at elevated temperature of 25,200 , 400, 600 deg cel

Compressive strength, tensile strength, flexural strength, XRD,

Transmission Electron Microscopy (TEM)

Compressive strength, water sorptivity, permeability, SEM

Compressive strength, SEM, XRD, XRF, FTIR, setting time
Remarks

With nano silica replacement at $10 \%$ the mechanical properties are higher and the microstructure of the pastes get improved

With increase in CS, the hydration mechanism also improved

NS with particle size

$1 \mu \mathrm{m}$ improved the compressive strength of the mortar.

The compressive strength stood higher with increase in NS and the microstructure was found denser at maximum replacement.

The mechanical properties improved with increase in NS concentration up to $2 \%$. NS decreases the water requirement for mixture and $2.5 \%$ replacement was found optimal. $3 \%$ replacement was found optimal and the compressive strength increased considerably with increase in NS content.

With increase in temperature and NS content the strength of the concrete reduces significantly. This strength reduction is due to the rise in temperature.

The NS improves the mortar matrix and also the strength increases with increase in NS.

GPC with $1 \%$ steel fibers and $2 \%$ NS possessed good properties.

$1.5 \%$ replacement was found optimal in both cases of NS and SF.

(continued) 
Table 1. Continued

\begin{tabular}{|c|c|c|c|c|c|}
\hline Ref. & Replacement material & \% Replacement & $\begin{array}{l}\text { Material in which } \\
\text { replacement done }\end{array}$ & Tests done & Remarks \\
\hline$[16]$ & NS & $@ 1,2,3 \%$ for cement & $\begin{array}{l}\text { Recycled aggregate } \\
\text { geopolymer concrete }\end{array}$ & $\begin{array}{c}\text { Compressive, flexural \& } \\
\text { tensile strength, water } \\
\text { absorption, sorptivity, } \\
\text { Rapid Chloride } \\
\text { Penetration Test } \\
\text { (RCPT) }\end{array}$ & $\begin{array}{l}\text { 1\% replacement of NS } \\
\text { improved both } \\
\text { mechanical and } \\
\text { durability properties of } \\
\text { GPC. }\end{array}$ \\
\hline$[17]$ & NS & $\begin{array}{l}@ 0.5,1,1.5,2,2.5,3 \% \\
\text { for fly ash }\end{array}$ & $\begin{array}{c}\text { Geopolymer concrete } \\
\text { (GPC) }\end{array}$ & $\begin{array}{c}\text { Compressive strength, } \\
\text { SEM }\end{array}$ & $\begin{array}{l}2 \% \text { NS replacement } \\
\text { shows increase in } \\
\text { compressive strength } \\
\text { and good } \\
\text { microstructure. }\end{array}$ \\
\hline$[18]$ & NS, SF \& fly ash (FA) & $\begin{array}{c}\text { SF }-10 \% \text { for cement } \\
\text { NS }-2 \% \text { for cement } \\
\text { FA }-5,10,15 \% \text { for } \\
\text { cement }\end{array}$ & $\begin{array}{l}\text { High-performance self- } \\
\text { compacting concrete }\end{array}$ & $\begin{array}{l}\text { Compressive, tensile \& } \\
\text { flexural strength, } \\
\text { Thermogravimetric } \\
\text { Analysis (TGA), water } \\
\text { absorption, RCPT }\end{array}$ & $\begin{array}{l}\text { Addition of NS at } 2 \% \\
\text { improved the } \\
\text { performance of } \\
\text { concrete. }\end{array}$ \\
\hline [19] & $\begin{array}{c}\text { Macro polymeric fibers, } \\
\text { polypropylene fibers, } \\
\text { NS, SF }\end{array}$ & $\begin{array}{c}\text { Macro polymeric fibers } \\
-0.25-2.5 \% @ 0.25 \% \\
\text { increment } \\
\text { Polypropylene fibers - }\end{array}$ & High-strength concrete & $\begin{array}{l}\text { Compressive and tensile } \\
\text { strength, water } \\
\text { absorption, density, } \\
\text { porosity }\end{array}$ & $\begin{array}{c}\text { NS@2\% and SF @ } 12 \% \\
\text { improved the } \\
\text { mechanical properties } \\
\text { of concrete. }\end{array}$ \\
\hline
\end{tabular}
$0.1-0.5 \% @ 0.1 \%$ increment

NS - 1, 2, 3\% SF - 8, 10, $12 \%$

[20] NS @0, 0.5, 1, 1.5, 2\% for cement

[21] SF, NS, Steel fibers \& Forta-ferro fibers NS

[23] NS, Cu-Zn ferrite, Ni ferrite

All the three were replaced@1,2,3,4,5\% for cement

[24] Micro silica (MS), NS

Micro silica - $12.5 \%$ NS $-2.5 \%$ for cement

[25] NS

$\mathrm{SF}-8,10,12 \%$

NS - 1, 2, 3\%

Steel fibers $-0.5,0.75,1$, $1.25,1.5 \%$

Forta-ferro fibers -0.2 , $0.35,0.5,0.65,0.8 \%$

@1, 2\% for cement
High-strength concrete

iber reinforced concrete

Ultra-high-strength
concrete

Pull out test, pore structure measurement, SEM, XRD, micro hardness

Compressive \& tensile strength, modulus of elasticity, water absorption, density

Compressive, tensile \& flexural strength, RCPT, water absorption, water sorptivity

High-strength concrete

Compressive, tensile \& flexural strength, modulus of elasticity

High-strength concrete

Compressive strength, SEM, DTA

Compressive \& tensile strength, spalling test
High-strength concrete

Compressive \& tensile
strength, spalling test

$@ 3 \%$ at $400,600,800{ }^{\circ} \mathrm{C}$ of elevated temperatures 
Table 1. Continued

\begin{tabular}{|c|c|c|c|c|c|}
\hline Ref. & Replacement material & \% Replacement & $\begin{array}{l}\text { Material in which } \\
\text { replacement done }\end{array}$ & Tests done & Remarks \\
\hline [26] & NS & $@ 1.5,3 \%$ for cement & $\begin{array}{l}\text { Recycled aggregate } \\
\text { concrete (RAC) }\end{array}$ & $\begin{array}{l}\text { Compressive strength, } \\
\text { bond strength, pull out } \\
\text { test, mass loss }\end{array}$ & $\begin{array}{l}1.5 \% \text { of NS in RAC } \\
\text { enhanced the bond } \\
\text { strength and corrosion } \\
\text { resistance. }\end{array}$ \\
\hline [27] & $\begin{array}{l}\text { Colloidal nano silica, } \\
\text { copper slag }\end{array}$ & $\begin{array}{c}\text { Colloidal NS }-0.5,1 \\
\begin{array}{c}1.5,2,2.5,3 \% \text { for } \\
\text { cement }\end{array}\end{array}$ & $\begin{array}{l}\text { High-performance } \\
\text { concrete }\end{array}$ & $\begin{array}{l}\text { Compressive, tensile \& } \\
\text { flexural strength, RCPT, } \\
\text { water absorption, } \\
\text { sorptivity, abrasion } \\
\text { resistance }\end{array}$ & $\begin{array}{l}\text { The mechanical \& } \\
\text { durability properties } \\
\text { increase with increase in } \\
\text { NS content but @ } 2 \% \\
\text { replacement was found } \\
\text { optimal. }\end{array}$ \\
\hline [28] & NS & $@ 0,4,6,8,10 \%$ & Geopolymer mortar & $\begin{array}{c}\text { Compressive, tensile \& } \\
\text { flexural strength, RCPT, } \\
\text { water absorption, SEM, } \\
\text { XRD }\end{array}$ & $\begin{array}{l}6 \% \text { addition of NS } \\
\text { improved the } \\
\text { mechanical properties } \\
\text { of the mortar. }\end{array}$ \\
\hline [29] & $\begin{array}{l}\text { NS, Basic oxygen steel } \\
\text { making slag (BOS) }\end{array}$ & $\begin{array}{c}\text { NS }-2 \% \\
\text { BOS }-25,50,75,100 \%\end{array}$ & High-strength concrete & $\begin{array}{l}\text { Compressive, tensile \& } \\
\text { flexural strength, water } \\
\text { absorption, ultra sonic } \\
\text { pulse velocity }\end{array}$ & $\begin{array}{l}50 \% \text { BOS @ } 2 \% \text { NS } \\
\text { increased the } \\
\text { compressive strength } \\
\text { and there was reduction } \\
\text { in the water absorption. }\end{array}$ \\
\hline [30] & NS & @1.5, 3\% & Concrete & $\begin{array}{c}\text { Compressive, tensile \& } \\
\text { flexural strength, RCPT, } \\
\text { XRD }\end{array}$ & $\begin{array}{l}\text { Using nano silica in } \\
\text { concrete increased the } \\
\text { compressive strength } \\
\text { and also had good } \\
\text { resistance to chloride } \\
\text { penetration. }\end{array}$ \\
\hline [31] & NS & $\begin{array}{l}@ 3,6,9,12 \% \text { and with } \\
\text { size } 12,20,40 \mathrm{~nm}\end{array}$ & Cement mortar & $\begin{array}{l}\text { Compressive strength, } \\
\text { particle size, SEM }\end{array}$ & $\begin{array}{c}\text { NS at } 9 \% \text { replacement } \\
\text { at all sizes were found } \\
\text { optimal. }\end{array}$ \\
\hline [32] & NS, SF & $\begin{array}{c}\text { NS }-0,1.5,3,5,7.5 \% \\
\text { SF - 0, 5, } 7.5 \% \text { for } \\
\text { cement }\end{array}$ & Concrete & $\begin{array}{l}\text { Compressive strength, } \\
\text { SEM, XRD, Energy } \\
\text { Dispersive X-ray } \\
\text { Spectroscopy (EDS) }\end{array}$ & $\begin{array}{c}3 \% \text { \& } 5 \% \text { replacement } \\
\text { of NS showed } \\
\text { improvement in } \\
\text { compressive strength. }\end{array}$ \\
\hline [33] & NS & $@ 3 \%$ & $\begin{array}{l}\text { High-strength light } \\
\text { weight concrete }\end{array}$ & $\begin{array}{l}\text { Compressive \& tensile } \\
\text { strength, gas } \\
\text { permeability, water } \\
\text { sorptivity }\end{array}$ & $\begin{array}{c}\text { NS enhances the } \\
\text { permeability, strength \& } \\
\text { durability of concrete in } \\
\text { aggressive } \\
\text { environments. }\end{array}$ \\
\hline [34] & NS & $@ 1,2,3,4 \%$ for cement & $\begin{array}{l}\text { Ultra-high-performance } \\
\text { concrete }\end{array}$ & $\begin{array}{l}\text { SEM, XRD, MIP, water } \\
\text { sorptivity }\end{array}$ & $\begin{array}{l}\text { Best performance was } \\
\text { obtained when NS was } \\
\text { replaced at } 3 \% \text { for } \\
\text { cement. }\end{array}$ \\
\hline [35] & NS & $@ 0,2,4,6 \%$ & Concrete & $\begin{array}{l}\text { Compressive strength, } \\
\text { electrical resistance, } \\
\text { weight loss, sorptivity, } \\
\text { water absorption }\end{array}$ & $\begin{array}{l}\text { NS shows positive } \\
\text { effects on mechanical } \\
\text { and durability } \\
\text { properties of concrete. }\end{array}$ \\
\hline [36] & NS & $@ 0.3,0.9 \%$ & Concrete & $\begin{array}{l}\text { Compressive strength, } \\
\text { SEM, sorptivity, RCPT, } \\
\text { water absorption, pore } \\
\text { size distribution }\end{array}$ & $\begin{array}{l}\text { With small amount of } \\
\text { NS at } 0.3 \% \text { itself the } \\
\text { durability of the } \\
\text { concrete gets improved. }\end{array}$ \\
\hline [37] & NS & @2, 4\% & $\begin{array}{l}\text { High volume fly ash } \\
\text { concrete }\end{array}$ & $\begin{array}{l}\text { Compressive strength, } \\
\text { sorptivity, permeable } \\
\text { voids, RCPT, porosity }\end{array}$ & $\begin{array}{c}2 \% \text { of NS for cement is } \\
\text { found to be superior to } \\
\text { normal concrete. }\end{array}$ \\
\hline [38] & $\begin{array}{l}\text { Micro silica (MS) and } \\
\text { nano silica }\end{array}$ & $\begin{array}{l}\text { MS - } 0,10 \% \\
\text { NS - 0, } 1,2 \%\end{array}$ & Cement mortar & $\begin{array}{l}\text { Sulphate attack, } \\
\text { carbonation, RCPT, } \\
\text { water absorption }\end{array}$ & $\begin{array}{l}\text { The combined effect of } \\
\text { NS with MS gave good } \\
\text { performance of mortar. }\end{array}$ \\
\hline
\end{tabular}

(continued) 
Table 1. Continued

\begin{tabular}{|c|c|c|c|c|c|}
\hline Ref. & Replacement material & $\%$ Replacement & $\begin{array}{l}\text { Material in which } \\
\text { replacement done }\end{array}$ & Tests done & Remarks \\
\hline [39] & NS \& fibers & $\begin{array}{c}\text { NS - 0, 2, 4, 6\% } \\
\text { Steel fiber - 0.2, } 0.3 \text {, } \\
0.5 \% \\
\text { Polypropylene fibers - } \\
0.1,0.15,0.2 \% \\
\text { Glass }-0.15,0.2,0.3 \%\end{array}$ & $\begin{array}{l}\text { Self-compacting } \\
\text { concrete }\end{array}$ & $\begin{array}{l}\text { Compressive, tensile \& } \\
\text { flexural strength, RCPT, } \\
\text { water absorption, } \\
\text { atomic force } \\
\text { microscopy, XRD }\end{array}$ & $\begin{array}{l}\text { The presence of both } \\
\text { fibers and nano silica } \\
\text { can improve the } \\
\text { mechanical and } \\
\text { durability properties of } \\
\text { concrete. }\end{array}$ \\
\hline$[40]$ & NS, Nano alumina & $\begin{array}{c}\mathrm{NS}-3,5,7 \% \\
\mathrm{NA}-1,2,3 \% \text { for } \\
\text { cement }\end{array}$ & Concrete & $\begin{array}{l}\text { Compressive strength, } \\
\text { loss of mass, change in } \\
\text { length, water absorption }\end{array}$ & $\begin{array}{l}\text { Nano alumina in } \\
\text { concrete showed better } \\
\text { results when compared } \\
\text { with nano silica. }\end{array}$ \\
\hline$[41]$ & NS & Not specified & Concrete & $\begin{array}{l}\text { Water permeability, } \\
\text { Environmental } \\
\text { Scanning Electron } \\
\text { Microscopy (ESEM) }\end{array}$ & $\begin{array}{l}\text { The microstructure of } \\
\text { concrete with NS is } \\
\text { more uniform than } \\
\text { conventional concrete. }\end{array}$ \\
\hline
\end{tabular}

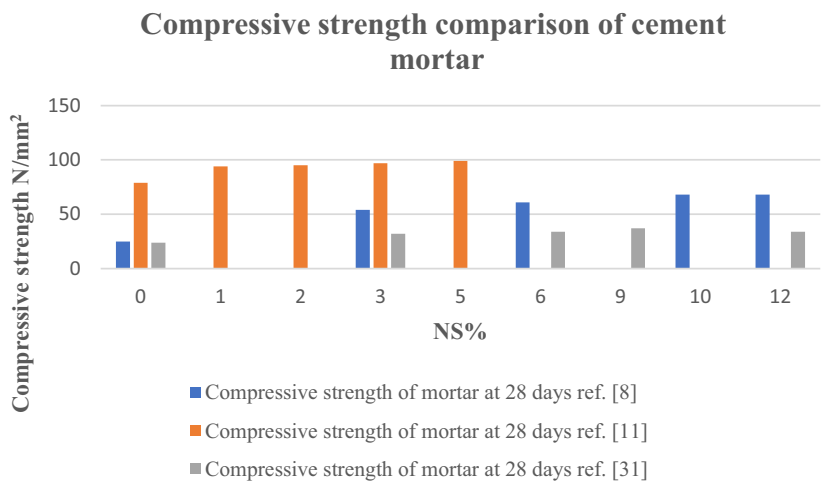

Fig. 1. Compressive strength comparison for cement mortar

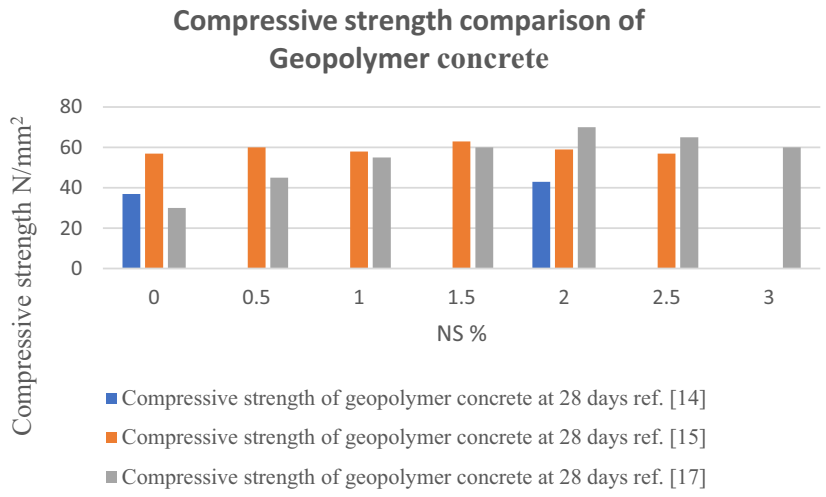

Fig. 2. Compressive strength comparison for geopolymer concrete

durability got increased significantly when compared with the control one [18]. S. Chithra et al. used nano silica in colloidal form and replaced at $2 \%$ for cement in high performance concrete and it increased the mechanical and durability properties of the concrete [27]. In an ultra-highperformance concrete, the performance was found best when nano silica was replaced at $3 \%$ for cement [34]. This is because of the fact that the pore structure of the concrete gets refined thus reducing the capillary pores and thus increasing the performance of the concrete $[18,27,34]$.

2.3.5. High-strength concrete. Nano silica also finds its application in high-strength concrete. Saber Fallah and Mahdi Nematzadeh used 2\% of nano silica and 12\% of silica fume to cement and it improved the mechanical properties of the high-strength concrete [19]. Mohamed Amin and Khaled Abu el-hassan manufactured high-strength concrete with nano silica and $\mathrm{Cu}$ and $\mathrm{Ni}$ ferrite where the mechanical properties improved and supported the high-strength of the concrete [23]. This may be due to the reaction of nano particles that form additional CSH gel thus improving the strength of the concrete $[19,23]$.

2.3.6. Fiber reinforced concrete. The combined effect of nano silica at $2 \%$ replacement for cement with silica fume at $8 \%$ and steel fibers at $1 \%$ possessed good mechanical properties in the case of fiber reinforced concrete. This is due to the presence of fibers, which will reduce the crack formation in concrete thus improving the properties of the concrete [21].

\subsection{Durability properties of concretes with nano silica}

2.4.1. Geopolymer concrete. Geopolymer concrete with $1 \%$ silica fume and $2 \%$ nano silica improved the durability of the manufactured concrete when compared with the control specimen [14]. There is a reduction in porosity due to the presence of NS thus it improved the durability of the concrete. Whereas in a recycled aggregate geopolymer concrete $1 \%$ addition of nano silica for cement had good resistance to chloride penetration and improved other durability properties of the concrete [16]. It is because the incorporation of NS enhanced the N-A-S-H gel and improved the durability of the concrete $[14,16]$.

2.4.2. High-performance concrete. Mostafa Jalal et al. in their study used $2 \%$ of NS and $10 \%$ of silica fume as a replacement to cement, which gave good resistance to water 
absorption and chloride penetration of high-performance self-compacting concrete [18]. The combined effect of NS with $\mathrm{SF}$ at $2 \%$ and $12 \%$, respectively, for cement in highperformance concrete improved the mechanical properties of the concrete [19]. Prakasam Ganesh et al. carried out a study with high-strength concrete in which $2 \%$ of nano silica was replaced for cement and the concrete possessed good durability properties. This is owed to the large specific surface area of nano silica and it also showed good pozzolanic reaction [22]. S. Chithra et al. added nano silica in colloidal form at various percentages in high-performance concrete and it has been found that the durability of the concrete increases with increase in the nano silica content, but $2 \%$ replacement was found to be optimal [27]. It is because the addition of nano silica to concrete improved the particle packing density of the matrix and enhanced the durability of the concrete [27].

2.4.3. High-strength concrete. The water absorption for the high-strength concrete gets reduced considerably when nano silica is added for cement as a replacement of $2 \%$. The reduction in water absorption is due to the micro filling effects of the nano silica [29].

2.4.4. Plain concrete. Mahdi Mahdikhani et al. replaced nano silica at various percentages for cement in normal concrete and they concluded that the NS shows positive effects on the durability of the concrete [35]. The durability of normal concrete is improved with even a small addition of nano silica to it. With $0.3 \%$ nano silica for cement itself the durability of the normal concrete gets improved when compared with the control one [36]. The mechanical properties of concrete containing nano silica showed better results than the concrete containing nano alumina in a study done by Kiachehr Behfarnia and Niloofar Salemi. This is due to the microstructure of the concrete getting improved by the addition of nano silica [40].

2.4.5. Other concretes. Steve Wilben Macquarie Supit and Faiz Uddin Ahmed Shaik manufactured high-volume fly ash concrete in which $2 \%$ replacement of nano silica is added to cement and it is found superior to the control specimen [37]. The combined effective utilization of nano silica with micro silica in cement mortar improves its performance considerably [38]. Along with nano silica in self-compacting concrete, the addition of fibers to it has improved the chloride resistance and also reduced the water requirement of the concrete [39]. This could be due to the changes in the microstructure of the concrete and the pore system.

\subsection{Fresh concrete properties}

NS was added at 0,2, $4 \& 6 \%$ by weight as a replacement for cement in self-compacting concrete. Slump flow, V funnel and $\mathrm{L}$ box are the tests done to determine the fresh concrete behavior in SCC. The addition of NS decreased the slump flow diameter, because NS was small in size and it has larger surface area which increases the water demand in the concrete. The flow time in $\mathrm{V}$ funnel increased due to the presence of NS whereas the passing ability of concrete with NS was good, however, when there was an increase in NS there was a slight reduction in the L box ratio [47]. Whereas in high-strength concrete, the workability of the concrete is reduced due to the presence of NS with its ability to absorb higher water as it is having higher specific surface area [19]. NS in self-compacting concrete decreased the workability of the mix and also little bleeding and segregation were observed in the mix containing NS. So, either the $\mathrm{w} / \mathrm{b}$ ratio needs to be increased or super plasticizers need to be added to maintain workability in self-compacting concrete [48].

In plain concrete, with the combined use of NS and micro silica, the workability of the mix was good and sufficient. Addition of NS required higher amount of super plasticizer (SP) to maintain the workability of the mix [49]. In recycled aggregate concrete, it was noticed that there is a loss of slump due to the presence of NS and it is due to the NS absorbing more water and hence reducing the fluidity of the mix [50].

Therefore, NS has higher water absorption, which reduces the workability of the mix. In order to overcome this the $\mathrm{w} / \mathrm{b}$ ratio has to be increased or the SP content needs to be added to make the mix workable [19, 47-50].

\section{CONCLUSIONS}

From the above study reviewed for nano silica used as construction material, the following conclusions can be brought:

1. Nano silica is found to be a good pozzolanic material, cementitious in nature and it was found suitable to utilize as a replacement material for cement as it also has a high silica content.

2. Nano silica finds its application in mortars, normal concretes and special concretes like high-performance concrete, self-compacting concrete, high-strength concrete, geopolymer concrete as a replacement for cement.

3. Nano silica has a higher specific surface area due to which it has a higher pore filling effect thus making the structure of the concrete denser, which directly improves the mechanical properties and durability of the material in which it is used.

4. Due to the higher specific surface area of the nano silica, the water absorption is higher, which needs to be maintained by changing the $\mathrm{w} / \mathrm{b}$ ratio or the superplasticizer dosage.

5. The concrete structure is denser as observed from the microstructural studies and this increases the bond properties of the concrete and also reduces the porosity as the pore system gets refined due to the addition of nano silica.

6. The incorporation of NS in concrete reduces the flowability of the mix and it is due to the high water demand required by the NS.

7. In cement mortar, the nano silica was replaced at $1-10 \%$ in various studies as a replacement for cement and NS at 
$2-3 \%$ replacement was found optimal and it also enhanced the strength of the mortar.

8. In the case of geopolymer concrete, nano silica replacement done for fly ash at $2 \%$ possessed good microstructural properties hence increasing the strength of the concrete too.

9. Ultra-high-strength concrete can be produced with good bond properties and dense microstructure with $1 \%$ of NS replacement for cement.

10. Incorporation of NS along with steel fibers in fiber reinforced concrete improvised good mechanical properties.

11. The mechanical and durability properties of self-compacting concrete can be enhanced by the combined effect of nano silica and fibers added to it.

Thus, from the above study it can be said that the NS can be effectively used as a replacement for cementitious materials especially cement to enhance the microstructural, strength and durability properties of the material in which it is used. In overall, it can be known that the utilization of nano silica as a construction material will be more advantageous thus improving the properties of the material in which it is used.

\section{REFERENCES}

[1] V. B. Carmona, R. M. Oliveira, W. T. L. Silva, L. H. C. Mahoso, and J. M. Marconcini, "Nano silica from rice husk: extraction and characterization,” Ind. Crops Prod., vol. 43, pp. 291-6, 2013. https://doi.org/10.1016/j.indcrop.2012.06.050.

[2] A. Lazaro, and H. J. H. Brouwers, "Nano-silica production by a sustainable process; application in building materials," in 8th fib PhD symposium in Kgs, Denmark, Lyngby, pp. 1-6, 2010.

[3] G. Quercia, A. Lazaro, J. W. Geus, and H. J. H. Brouwers, "Characterization of morphology and texture of several amorphous nano-silica particles used in concrete," Cement Concr. Compos., vol. 44, pp. 77-92, 2013. https://doi.org/10.1016/j. cemconcomp.2013.05.006.

[4] T.-H. Liou, and C.-C. Yang, "Synthesis and surface characteristics of nano silica produced from alkali-extracted rice husk ash," Mater. Sci. Eng. B, vol. 176, pp. 521-9, 2011. https://doi.org/10. 1016/j.mseb.2011.01.007.

[5] H. Li, H.-G. Xiao, J. Yuan, and J. Ou, "Microstructure of cement mortar with nano-particles," Composites B., vol. 35, 2004, pp. 185-9. https://doi.org/10.1016/S1359-8368(03)00052-0.

[6] J. Bjornstorm, A. Martinelli, A. Matic, L. Borjesson, and I. Panas, "Accelerating effects of colloidal nano-silica for beneficial calciumsilicate-hydrate formation in cement," Chem. Phys. Lett., vol. 392, pp. 242-8, 2004. https://doi.org/10.1016/j.cplett.2004.05.071.

[7] K. L. Lin, W. C. Chang, D. F. Lin, H. L. Luo, and M. C. Tsai, "Effects of nano $\mathrm{SiO}_{2}$ and different ash particles sizes on sludge ash cement mortar," J. Environ. Manage., vol. 88, pp. 708-14, 2008. https://doi.org/10.1016/j.jenvman.2007.03.036.

[8] B.-W. Jo, C.-H. Kim, G.-H. Tae, and P. Jong-Bin, "Characteristics of cement mortar with nano $\mathrm{SiO}_{2}$ particles," Construct. Build.
Mater., vol. 21, pp. 1351-5, 2007. https://doi.org/10.1016/j. conbuildmat.2005.12.020.

[9] M. Stefanidou, and I. Papayianni, "Influence of nano $\mathrm{SiO}_{2}$ on the Portland cement pastes," Composites B., vol. 43, pp. 2706-10, 2012. https://doi.org/10.1016/j.compositesb.2011.12.015.

[10] L. Senff, J. A. Labrincha, and V. M. Ferreira, D. Hotza, and W. L. Repette, "Effect of nano-silica on rheology and fresh properties of cement pastes and mortars," Construct. Build. Mater., vol. 23, pp. 2487-91, 2009. https://doi.org/10.1016/j.conbuildmat.2009.02.005.

[11] Q. Ye, Z. Zhang, D. Kong, and R. Chen, "Influence of nano- $\mathrm{SiO}_{2}$ addition on properties of hardened cement paste as compared with silica fume," Construct. Build. Mater., vol. 21, pp. 539-45, 2007. https://doi.org/10.1016/j.conbuildmat.2005.09.001.

[12] Y. Wang, S. Li, P. Hughes, and Y. Fan, "Mechanical properties and microstructure of basalt fibre and nano-silica reinforced recycled concrete after exposure to elevated temperatures," Construct. Build. Mater., vol. 247, p. 118561, 2020. https://doi.org/10.1016/j. conbuildmat.2020.118561.

[13] B. Bhusan Mukharjee, and S. V. Barai, "Influence of incorporation of colloidal nano-silica on behaviour of concrete," Iranian J. Sci. Technol. Trans. Civil Eng., vol. 44, pp. 657-68, 2020. https://doi. org/10.1007/s40996-020-00382-0.

[14] J. Musdif Their, and M. Ozakca, "Developing geopolymer concrete by using cold-bonded fly ash aggregate, nano-silica and steel fiber," Construct. Build. Mater., vol. 180, pp. 12-22, 2018. https:// doi.org/10.1016/j.conbuildmat.2018.05.274.

[15] S. M. Mustakim, S. K. Das, J. Mishra, A. Aftab, T. S. Alomayri, H. S. Assaedi, and C. R. Kaze, "Improvement in fresh, mechanical and microstructural properties of fly ash-blast furnace slag based geopolymer concrete by addition of nano and micro silica," Silicon, 2020. https://doi.org/10.1007/s12633-020-00593-0.

[16] N. Peem, V. Sata, A. Wongsa, K. Srinavin, and P. Chindaprasirt, "Recycled aggregate high calcium fly ash geopolymer concrete with inclusion of OPC and nano-SiO ${ }_{2}$," Construct. Build. Mater., vol. 174, pp. 244-52, 2018. https://doi.org/10.1016/j.conbuildmat. 2018.04.123.

[17] P. S. Deb, P. K. Sarker, and S. Barbhuiya, "Effects of nano silica on the strength development of geopolymer cured at room temperature," Construct. Build. Mater., vol. 101, pp. 675-83, 2015. https://doi.org/10.1016/j.conbuildmat.2015.10.044.

[18] M. Jalal, A. Pouladkhan, O. F. Harandi, and D. Jafari, "Comparative study on effects of class F fly ash, nano silica and silica fume on properties of high-performance self compacting concrete," Construct. Build. Mater., vol. 94, pp. 90-104, 2015. https://doi.org/ 10.1016/j.conbuildmat.2015.07.001.

[19] S. Fallah, and M. Nematzadeh, "Mechanical properties and durability of high-strength concrete containing macro-polymeric and polypropylene fibers with nano-silica and silica fume," Construct. Build. Mater., vol. 132, pp. 170-87, 2017. https://doi. org/10.1016/j.conbuildmat.2016.11.100.

[20] Z. Wu, K. H. Khayat, and C. Shi, "Effect of nano-SiO 2 particles and curing time on development of fiber-matrix bond properties and microstructure of ultra-high strength concrete," Cement Concrete Res., vol. 95, pp. 247-56, 2017. https://doi.org/10.1016/j. cemconres.2017.02.031.

[21] F. Hasan-Nattaj, and M. Nematzadeh, "The effect of forta-ferro and steel fibers on mechanical properties of high-strength concrete with ad without silica fume nano-silica," Construct. Build. Mater., 
vol. 137, pp. 557-72, 2017. https://doi.org/10.1016/j.conbuildmat. 2017.01.078.

[22] P. Ganesh, A. R. Murthy, S. Sundar Kumar, M. Mohammed Saffic Reheman, and N. R. Iyer, "Effect of nano-silica on durability and mechanical properties of high-strength concrete," Mag. Concrete Res., vol. 68, no. 5, pp. 229-36, 2016. https://doi.org/10.1680/ jmacr.14.00338.

[23] M. Amin, and K. Abu el-hassan, "Effect of using different types of nano materials on mechanical properties of high strength concrete," Construct. Build. Mater., vol. 80, pp. 116-24, 2015. https:// doi.org/10.1016/j.conbuildmat.2014.12.075.

[24] N. Toropovs, D. Bajare, G. Sahmenko, L. Krage, and A. Korjakins, "The formation of microstructure in high strength concrete containing micro and nano silica," Key Eng. Mater., vol. 604, pp. 83-6, 2014. https://doi.org/10.4028/www.scientific.net/KEM.604.83.

[25] M. Bastami, M. Baghbadrani, and F. Aslani, "Performance of nano-silica modified high strength concrete at elevated temperatures," Construct. Build. Mater., vol. 68, pp. 402-8, 2014. https:// doi.org/10.1016/j.conbuildmat.2014.06.026.

[26] M. Alhawat, and A. Ashour, "Bond strength between corroded steel and recycled aggregate concrete incorporating nano silica," Construct. Build. Mater., vol. 237, p. 117441, 2020. https://doi.org/ 10.1016/j.conbuildmat.2019.117441.

[27] S. Chithra, S. R. R. Senthil Kumar, and K. Chinnaraju, "The effect of colloidal nano-silica on workability, mechanical and durability properties of high-performance concrete with copper slag as partial fine aggregate," Construct. Build. Mater., vol. 113, pp. 794-804, 2016. https://doi.org/10.1016/j.conbuildmat.2016.03.119.

[28] D. Adak, M. Sarkar, and S. Mandal, "Effect of nano-silica on strength and durability of fly ash based geopolymer mortar," Construct. Build. Mater., vol. 70, pp. 453-9, 2014. https://doi.org/ 10.1016/j.conbuildmat.2014.07.093.

[29] S. A. Zareei, F. Ameri, N. Bahrami, P. Shoaei, R. M. Hamid, and N. Salemi, "Performance of sustainable high strength concrete with basic oxygen steel-making (BOS) slag and nano-silica," J. Build. Eng., vol. 25, p. 100791, 2019. https://doi.org/10.1016/j.jobe.2019. 100791.

[30] S. Gopinath, P. C. H. Mouli, A. R. Murthy, N. R. Iyer, and S. Maheswaran, "Effect of nano silica on mechanical properties and durability of normal strength concrete," Arch. Civil Eng., vol. 58, no. 4, pp. 433-44, 2012. https://doi.org/10.2478/v.10169-012$0023-y$.

[31] S. Haruehansapong, T. Pulngern, and S. Chucheepsakul, "Effect of the particle size of nano silica on the compressive strength and the optimum replacement content of cement mortar containing nano$\mathrm{SiO}_{2}$," Construct. Build. Mater., vol. 50, pp. 471-7, 2014. https:// doi.org/10.1016/j.conbuildmat.2013.10.002.

[32] M. Nili, and E. Ahmad, "Investigating the effect of the cement paste and transition zone on strength development of concrete containing nano silica and silica fume," Mater. Des., vol. 75, pp. 174-83, 2015. https://doi.org/10.1016/j.matdes.2015.03.024.

[33] N. Atmaca, M. L. Abbas, and A. Atmaca, "Effects of nano-silica on the gas permeability, durability and mechanical properties of highstrength light weight concrete," Construct. Build. Mater., vol. 147, pp. 17-26, 2017. https://doi.org/10.1016/j.conbuildmat.2017.04. 156.

[34] E. Ghafari, H. Costa, E. Julio, A. Portugal, and L. Duraes, "The effect of nano silica addition on flowability, strength and transport properties of ultra high-performance concrete," Mater. Des., vol. 59, pp. 1-9, 2014. https://doi.org/10.1016/j.matdes.2014.02.051.

[35] M. Mahdikhani, O. Bamshad, and M. Fallah Shirvani, "Mechanical properties and durability of concrete specimens containing nano silica in sulphuric acid rain condition," Construct. Build. Mater., vol. 167, pp. 929-35, 2018. https://doi.org/10.1016/j. conbuildmat.2018.01.137.

[36] H. Du, S. Du, and X. Liu, "Durability performance of concrete with nano-silica," Construct. Build. Mater., vol. 73, pp. 705-12, 2014. https://doi.org/10.1016/j.conbuildmat.2014.10.014.

[37] S. W. Macquarie Supit, and F. U. Ahmed Shaik, "Durability properties of high-volume fly ash concrete containing nano-silica," Mater. Struct., vol. 48, pp. 2431-45, 2014. https://doi.org/10.1617/ s11527-014-0329-0.

[38] L. G. Li, J. Zhu, Z. H. Huang, A. K. H. Kwan, and L. J. Li, "Combined effects of micro-silica and nano-silica on durability of mortar," Construct. Build. Mater., vol. 157, pp. 337-47, 2017. https://doi.org/10.1016/j.conbuildmat.2017.09.105.

[39] M. H. Beigi, J. Berenjian, O. L. Omran, A. S. Nik, and I. M. Nikbin, "An experimental survey on combined effects of fibers and nano silica on the mechanical, rheological and durability properties of self-compacting concrete," Mater. Des., vol. 50, pp. 1019-29, 2013. https://doi.org/10.1016/j.matdes.2013.03.046.

[40] K. Behfarnia, and N. Salemi, "The effects of nano-silica and nanoalumina on frost resistance of normal concrete," Construct. Build. Mater., vol. 48, pp. 580-4, 2013. https://doi.org/10.1016/j. conbuildmat.2013.07.088.

[41] J. Tao, "Preliminary study on the water permeability and microstructure of concrete containing nano $\mathrm{SiO}_{2}$," Cement Concr. Res., vol. 35, pp. 1943-7, 2005. https://doi.org/10.1016/j.cemconres.2005.07.004.

[42] J. Alex, J. Dhanalakshmi, and B. Ambedkar, "Experimental investigation on rice husk ash as cement replacement on concrete production," Construct. Build. Mater., vol. 127, pp. 353-62, 2016. https://doi.org/10.1016/j.conbuildmat.2016.09.150.

[43] K. P. Daman, Developments in the Formulation and Reinforcement of Concrete, 2nd ed. Woodhead Publishing, 2019.

[44] H. S. Lee, B. Balasubramanian, G. V. T. Gopalakrishna, K. SeungJun, S. P. Karthick, and V. Saraswathy, "Durability performance of CNT and nanosilica admixed cement mortar," Construct. Build. Mater., vol. 159, pp. 463-72, 2018. https://doi.org/10.1016/j. conbuildmat.2017.11.003.

[45] L. P. Singh, S. R. Karade, S. K. Bhattacharyya, M. Mohamed Yousuf, and S. Ahalawat, "Beneficial role of nanosilica in cement based materials - a review," Construct. Build. Mater., vol. 47, pp. 1069-77, 2013. https://doi.org/10.1016/j.conbuildmat.2013.05.052.

[46] M. Schneider, M. Romer, M. Tschudin, and H. Bolio, "Sustainable cement production-present and future," Cement concrete Res., vol. 41, no. 7, pp. $642-50,2011$. https://doi.org/10.1016/j. cemconres.2011.03.019.

[47] E. Güneyisi, M. Gesoglu, A. Al-Goody, and S. İpek, "Fresh and rheological behavior of nano-silica and fly ash blended self-compacting concrete," Construct. Build. Mater., vol. 95, pp. 29-44, 2015. https://doi.org/10.1016/j.conbuildmat.2015.07.142.

[48] N. Hani, N. Omar, K. S. Ragab, and K. Mohamed, "The effect of different water/binder ratio and nano-silica dosage on the fresh and hardened properties of self-compacting concrete," Construct. Build. Mater., vol. 165, pp. 504-13, 2018. https://doi.org/10.1016/j. conbuildmat.2018.01.045. 
[49] L. G. Li, J. Y. Zheng, J. Zhu, and A. K. H. Kwan, "Combined usage of micro-silica and nano-silica in concrete: SP demand, cementing efficiencies and synergistic effect," Construct. Build. Mater., vol. 168, pp. 622-32, 2018. https://doi.org/10.1016/j.conbuildmat.2018.02.181.
[50] B. B. Mukharjee, and S. V. Barai, "Influence of nano-silica on the properties of recycled aggregate concrete," Construct. Build. Mater., vol. 55, pp. 29-37, 2014. https://doi.org/10.1016/j. conbuildmat.2014.01.003.

Open Access. This is an open-access article distributed under the terms of the Creative Commons Attribution-NonCommercial 4.0 International License (https:// creativecommons.org/licenses/by-nc/4.0/), which permits unrestricted use, distribution, and reproduction in any medium for non-commercial purposes, provided the original author and source are credited, a link to the CC License is provided, and changes - if any - are indicated. 